2020

\title{
Bony-Tongue Fishes (Teleostei: Osteoglossomorpha) from the Eocene Nanjemoy Formation, Virginia
}

Eric J. Hilton

Virginia Institute of Marine Science

Jeffrey Carpenter

Follow this and additional works at: https://scholarworks.wm.edu/vimsarticles

Part of the Other Ecology and Evolutionary Biology Commons

\section{Recommended Citation}

Hilton, Eric J. and Carpenter, Jeffrey, Bony-Tongue Fishes (Teleostei: Osteoglossomorpha) from the Eocene Nanjemoy Formation, Virginia (2020). Northeastern Naturalist, 27(1), 25-34.

DOI: $10.1656 / 045.027 .0102$

This Article is brought to you for free and open access by the Virginia Institute of Marine Science at W\&M ScholarWorks. It has been accepted for inclusion in VIMS Articles by an authorized administrator of W\&M ScholarWorks. For more information, please contact scholarworks@wm.edu. 


\title{
Bony-Tongue Fishes (Teleostei: Osteoglossomorpha) from the Eocene Nanjemoy Formation, Virginia
}

\author{
Eric J. Hilton ${ }^{1, *}$ and Jeffrey Carpenter ${ }^{2}$
}

\begin{abstract}
Bony-tongue fishes, Osteoglossomorpha, are distributed in North and South America, Africa, Asia, and Australia and are found on all continents except Antarctica in the fossil record. The group includes fishes such as the mooneyes (Hiodontidae), freshwater knifefishes (Notopteridae), elephantfishes (Mormyridae), and the arowanas and pirarucu (Osteoglossidae). Remains identified as belonging to the family Osteoglossidae are known from the Nanjemoy Formation of Maryland and northern Virginia and comprise isolated teeth and fragmentary jaw bones assigned to the now extinct $\uparrow$ Brychaetus muelleri. The second author discovered a partial toothed parasphenoid among other isolated and fragmentary vertebrate microfossils from the Fisher-Sullivan Site of the Nanjemoy Formation in northern Virginia. This element resembles the base of the parasphenoid of the extant osteoglossid taxa Osteoglossum and Scleropages. Although this fossil is fragmentary and not sufficient to differentially diagnose taxonomically, it provides further evidence of the substantial diversity of Osteoglossidae during the Eocene.
\end{abstract}

\section{Introduction}

Osteoglossomorpha, the bony-tongue fishes, comprise an iconic group of freshwater fishes found today in North and South America, Africa, Asia, and Australia, and all continents except Antarctica in the fossil record. The group includes fishes such as the mooneyes (Hiodontidae), freshwater knifefishes (Notopteridae), elephantfishes (Mormyridae), and the arowanas and pirarucu (Osteoglossidae). For a recent review of the systematic biology and biogeography of Osteoglossomorpha, see Hilton and Lavoué (2018). Uniquely among many groups of teleostean fishes, Osteoglossomorpha is represented in its fossil record by a greater number of genera than its extant members. Several morphological characteristics define this group of fishes, including both derived (e.g., presence of only 4 infraorbital bones, and absence of the supraorbital and supramaxilla bones) and plesiomorphic (e.g., the presence of a toothed parasphenoid) characters (Hilton 2003). There are about 250 species of living osteoglossomorphs, although more than 200 (and about 21 genera) of these are in the single, indisputably monophyletic family Mormyridae. There are over 35 genera of fossil osteoglossomorphs, with most being included in the family Osteoglossidae (Hilton and Lavoué 2018). The fossil record of osteoglossids is as interesting as it is diverse, being distributed across the globe, extending back to the Late Cretaceous, and found in both marine and freshwater deposits. The Eocene stands out as the peak of osteoglossid diversity (Hilton and Lavoué 2018).

\footnotetext{
${ }^{1}$ Virginia Institute of Marine Science, William \& Mary, Gloucester Point, VA 23062. ${ }^{2} 12789$ Fair Crest Court \#303 Fairfax, VA 22033. *Corresponding author - ehilton@vims.edu.
}

Manuscript Editor: Giorgio Carnevale 
Osteoglossids are represented in the Nanjemoy Formation of Maryland and northern Virginia by isolated teeth and fragmentary jaw bones assigned to $\uparrow$ Brychaetus muelleri (note: dagger symbol indicates taxa that are represented only by fossils) (Weems 1999, Weems and Horman 1983). †Brychaetus and related forms have a distinctive tooth morphology, being antero-posteriorly compressed and bearing a tall collar of rough bone supporting the smooth portion of the tooth (see Discussion). $\dagger$ Brychaetus is part of the $\uparrow$ Phareodontinae, which also includes taxa such as $\uparrow$ Cretophareodus (Late Cretaceous, North America), $\uparrow$ Phareodus (Eocene, North America, Australia), and $\uparrow$ Musperia (Oligocene-Eocene, Sumatra; see Murray et al. 2015); other putative allies include $\uparrow$ Taverneichthys (Late Cretaceous, India), $\uparrow$ Ridewoodichthys (Paleocene, Cabinda Province, Africa), $\uparrow$ Brychaetoides (early Eocene, Denmark), $\uparrow$ Phareodusichthys (late early Paleocene, Bolivia), $\uparrow M o-$ nopteros (early Eocene, Monte Bolca), $\uparrow$ Xosteoglossid (early Eocene, Denmark), and $\uparrow$ Magnigena (late Paleocene, Saudi Arabia); see Bonde (2008), Forey and Hilton (2010) and Hilton and Lavoué (2018) for a more complete discussion of the systematic relationships among fossil osteoglossids.

The second author discovered a partial parasphenoid among other isolated and fragmentary microfossils from the Fisher-Sullivan Site of the Nanjemoy Formation in northern Virginia (Fig. 1); this find resembles the base of the parasphenoid of the extant osteoglossid genera Osteoglossum and Scleropages. Although this

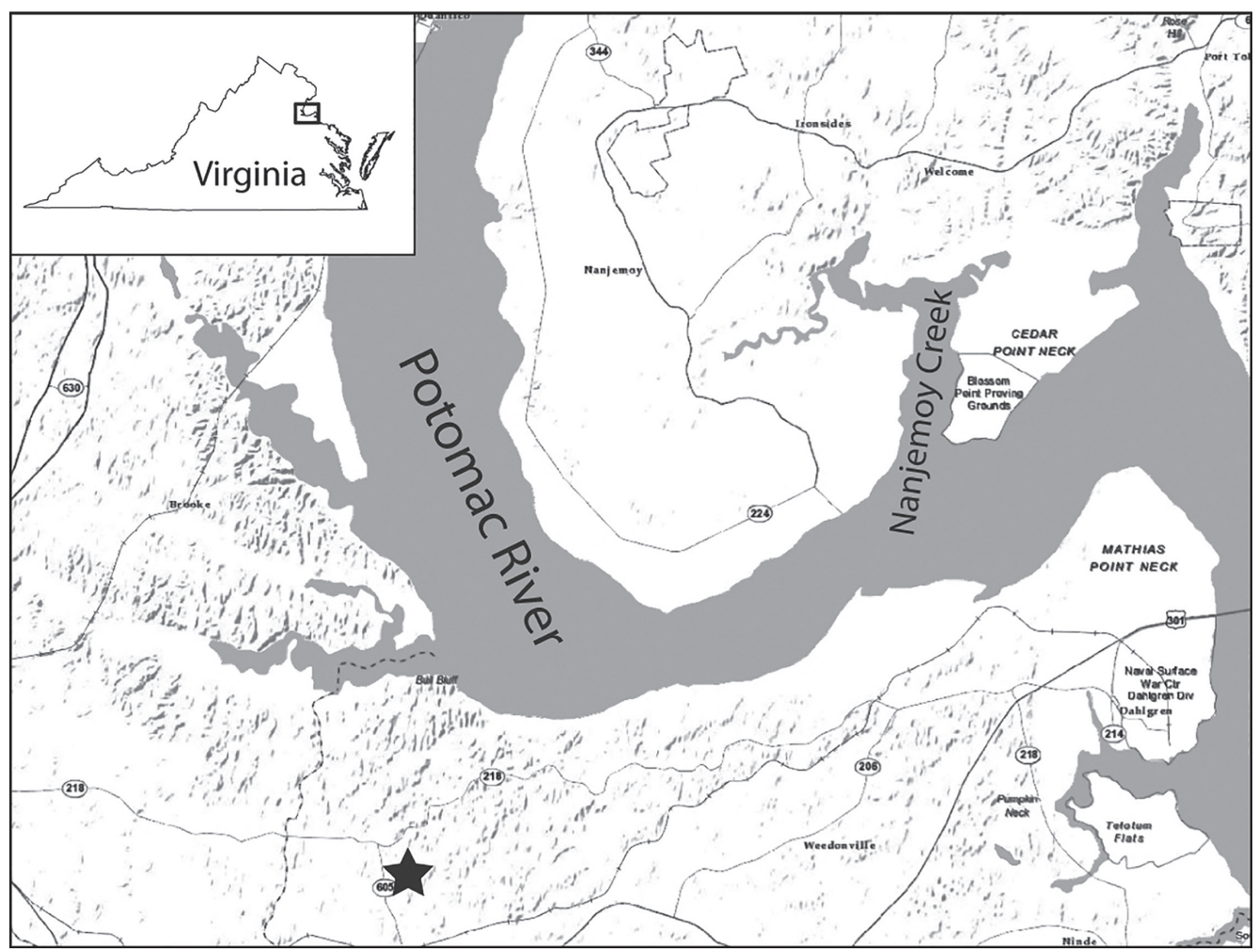

Figure 1. Map showing location of the Nanjemoy Formation and collection site (indicated by the star). 
fossil is fragmentary and not sufficient to differentially diagnose taxonomically, it is still important because it provides strong evidence for additional diversity of Osteoglossidae during the Eocene and the broad distribution of this family (both geographically and temporally). The goal of this paper is to describe this fossil and provide comparisons to other osteoglossid fishes. In particular, we compare it to $\uparrow$ Brychaetus, although the revision of $\uparrow$ Brychaetus and $\uparrow$ Brychaetus-like taxa is beyond the scope of the present paper.

\section{Field-Site Description}

The specimen described herein was collected in 2001 from property then owned by Mr. Russel Sullivan. Mr. Sullivan gave permission to several amateur paleontologists to excavate on his property under the supervision of Dr. Robert Weems (US Geological Survey, emeritus scientist, Herndon, VA). The site was designated as the Fisher-Sullivan site (Weems and Grimsley 1999).

The Early Eocene (Ypresian) Nanjemoy Formation (Fig. 2) is part of the Paleocene-Eocene Pamunkey Group, which includes the Brightseat, Aquia, Nanjemoy, and Piney Point formations and spans from the Danian to the Lutetian (ca. 65 MYA to ca. 40 MYA). The Nanjemoy Formation, which consists of sands and clays, is exposed along the Potomac River and tributaries in northeastern Virginia and southeastern Maryland (Fig. 1). For more detail on the geology of the Nanjemoy, see Weems and Grimsley (1999). This formation produces a broad array of plant, mollusk, and vertebrate fossils, representing the fauna of the nearshore North American Atlantic Coastal Plain during the Paleogene. The Potapaco Member of the Nanjemoy, from which the described fossil was found, was deposited on the western shore of the North Atlantic and contemporaneously with the London Clay Formation along the eastern shore of the North Atlantic.

\section{Methods}

Bulk material was excavated from an exposed portion of Potapaco Bed B at the Fisher-Sullivan site (Weems and Grimsley 1999). The excavated material was first screened at the site using a $6.35-\mathrm{mm}$ mesh, and the sieved material was screened again using a 1-mm mesh. The described specimen, along with numerous other fossils, was discovered through this screening process. The specimen (USNM 726309) is deposited in the collections of the United States National Museum of Natural History (Smithsonian Institution).

The specimen discussed herein was photographed using a Zeiss Axio-Cam highresolution camera attached to a Zeiss Discovery V20 microscope. Z-stacked images were assembled using Axiocam software to increase the depth of field. We scanned images and adjusted for brightness and contrast using Adobe Photoshop. The specimen was drawn based on photographs.

Institutional acronyms follow Sabaj (2019). 
Figure 2. Geological time scale of the Pamunkey Group, including the Nanjemoy Formation (modified from Weems and Grimsley, 1999). The position of the remains described herein is indicated by the star.

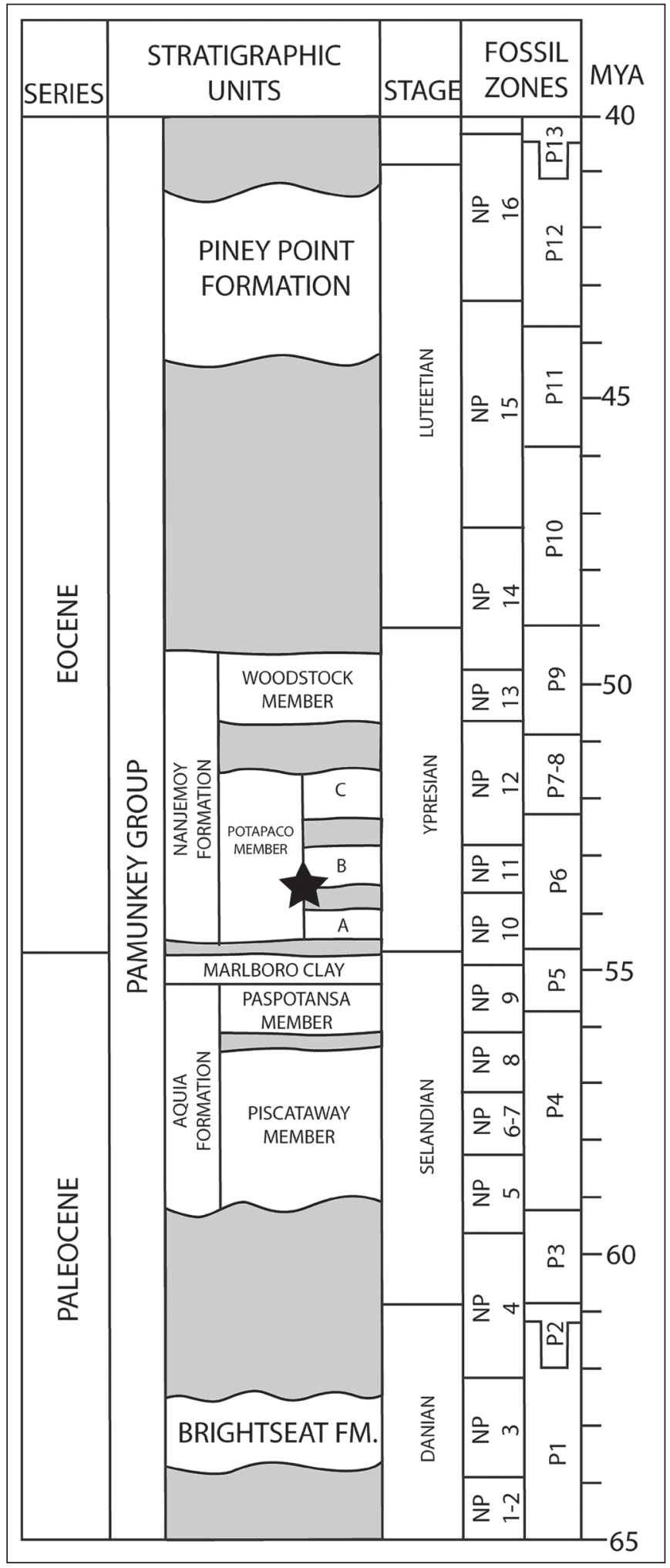




\section{Results}

\section{Osteoglossidae indeterminate genus}

This description is based on a single, isolated, and fragmentary element (Fig. 3). The specimen consists of the median portion of a parasphenoid. The fossil is small,

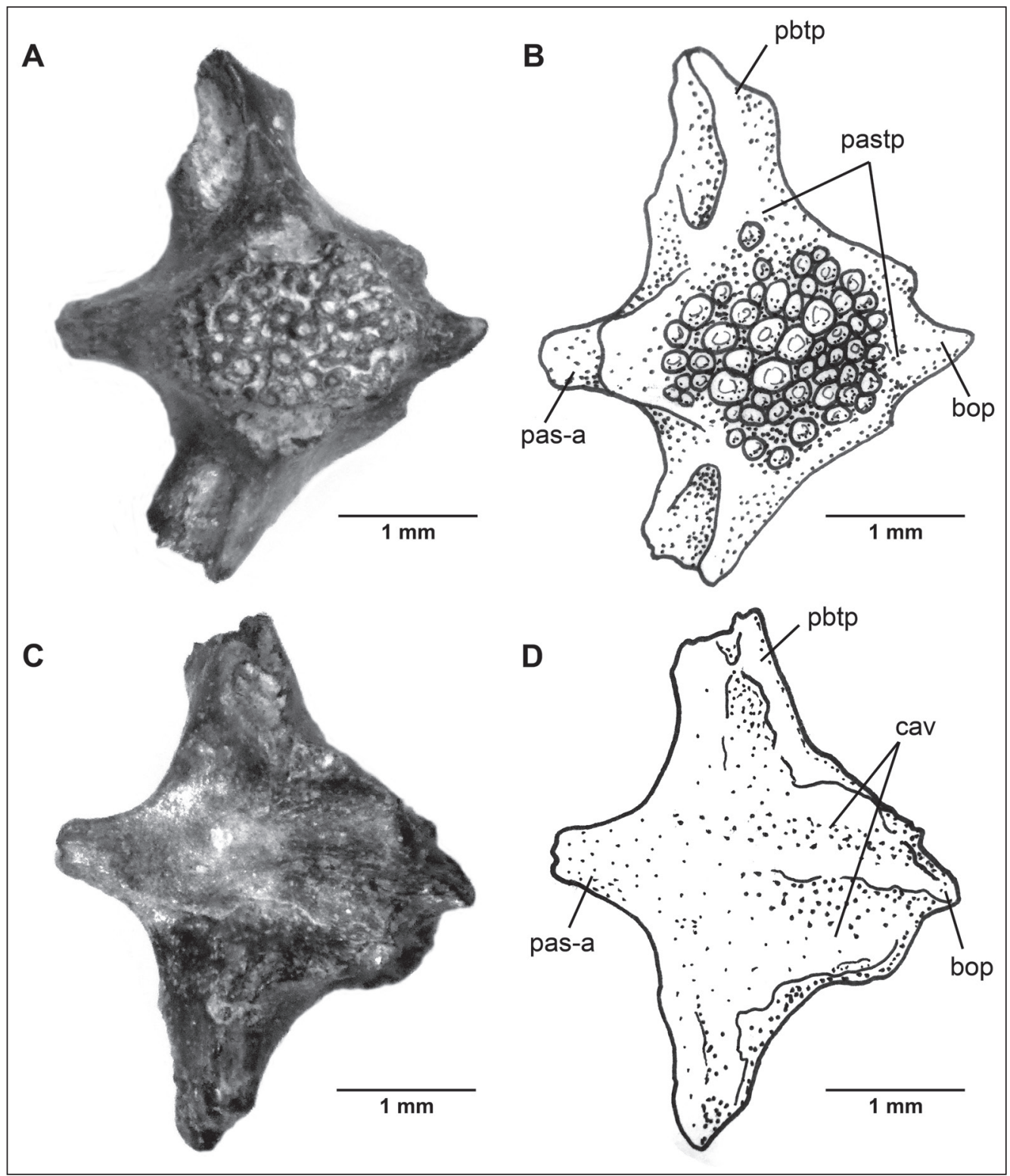

Figure 3. Isolated and fragmentary osteoglossomorph parasphenoid from the Nanjemoy Formation (USNM 726309). (A) Photograph and (B) line drawing of specimen in ventral view. (C) Photograph and (D) line drawing in dorsal view. Anterior to left. Abbreviations: bop $=$ basioccipital process of the parasphenoid, cav $=$ cavities of the internal surface of the braincase, pas-a = anterior process of the parasphenoid, pastp = parasphenoid tooth patch, and $\mathrm{pbtp}=$ basipterygoid process of the parasphenoid. 
measuring just $3.1 \mathrm{~mm}$ antero-posteriorly. Although it is fragmentary, the parasphenoid would have been quite small even as a complete element; it is unknown, however, whether this is from a small juvenile or from a small-sized adult. On its ventral surface is a small median tooth patch comprising $\sim 54$ teeth (Fig. 3A, B), although there were likely additional teeth present in life. The only portion of the teeth that remain are the bases where they were ankylosed to the underlying parasphenoid, which appear as round collars of bone.

The preserved portion of the parasphenoid includes short, broken anterior and posterior processes that would articulate with the vomer and basioccipital, respectively (Fig. 3). Also preserved are the bases of the left and right basipterygoid processes; both processes are broken distally. On their ventral surfaces, the basipterygoid processes bear deep concavities.

The dorsal surface of the parasphenoid is marked by a pair of sulci, which likely formed the internal surface of the braincase and housed portions of the inner ear (Fig. 3C, D).

In general form, the preserved portion of the parasphenoid agrees well with the morphology of this region of the parasphenoid of other osteoglossids that possess a parasphenoid tooth patches, such as Osteoglossum (Fig. 4) and Scleropages (E.J. Hilton, pers. observ.). The fossil appears to have a greater number of teeth (54) than either Osteoglossum or Scleropages (49 and 22, respectively, on specimens available for observation here: O. bichirrosum, VIMS 35940, S. jardini, USNM 217049), although the range of variation for the extant taxa is unknown. The parasphenoid of Pantodon, which is sometimes included within Osteoglossinae, also bears teeth (27 in CU 87447), but they are arranged along much of the length of the parasphenoid rather than in a cluster at the level of the basipterygoid processes (Hilton 2003:fig. $18 \mathrm{G})$.

\section{$\uparrow$ Brychaetus-like teeth and jaws}

Isolated teeth allied to $\uparrow$ Brychaetus are relatively common in the Nanjemoy Formation (Weems and Horman, 1983). These teeth are antero-posteriorly compressed and bear a distinct collar of bone that extends over half of the length of the tooth (Fig. 5B). There are specimens of teeth that are associated with fragmentary underlying dentigerous bones (e.g., dentary), but these are rare (see Weems and Horman 1983:fig. 4).

\section{Discussion}

Among extant teleostean fishes, few groups retain toothed parasphenoid bones, which is a plesiomorphic character at least at the level of Neopterygii, if not Actinopterygii. Among these groups, Osteoglossomorpha is unusual in having these teeth enlarged (Hilton 2003). In most other fishes that have parasphenoid dentition, these teeth are small and shagreen-like. The only non-osteoglossomorph teleosts with greatly enlarged parasphenoid teeth are albulids (Elopomorpha), and these are greatly enlarged molariform teeth that have bases quite unlike the bases preserved in the fossil discussed here from the Nanjemoy Formation. The morphology of the 

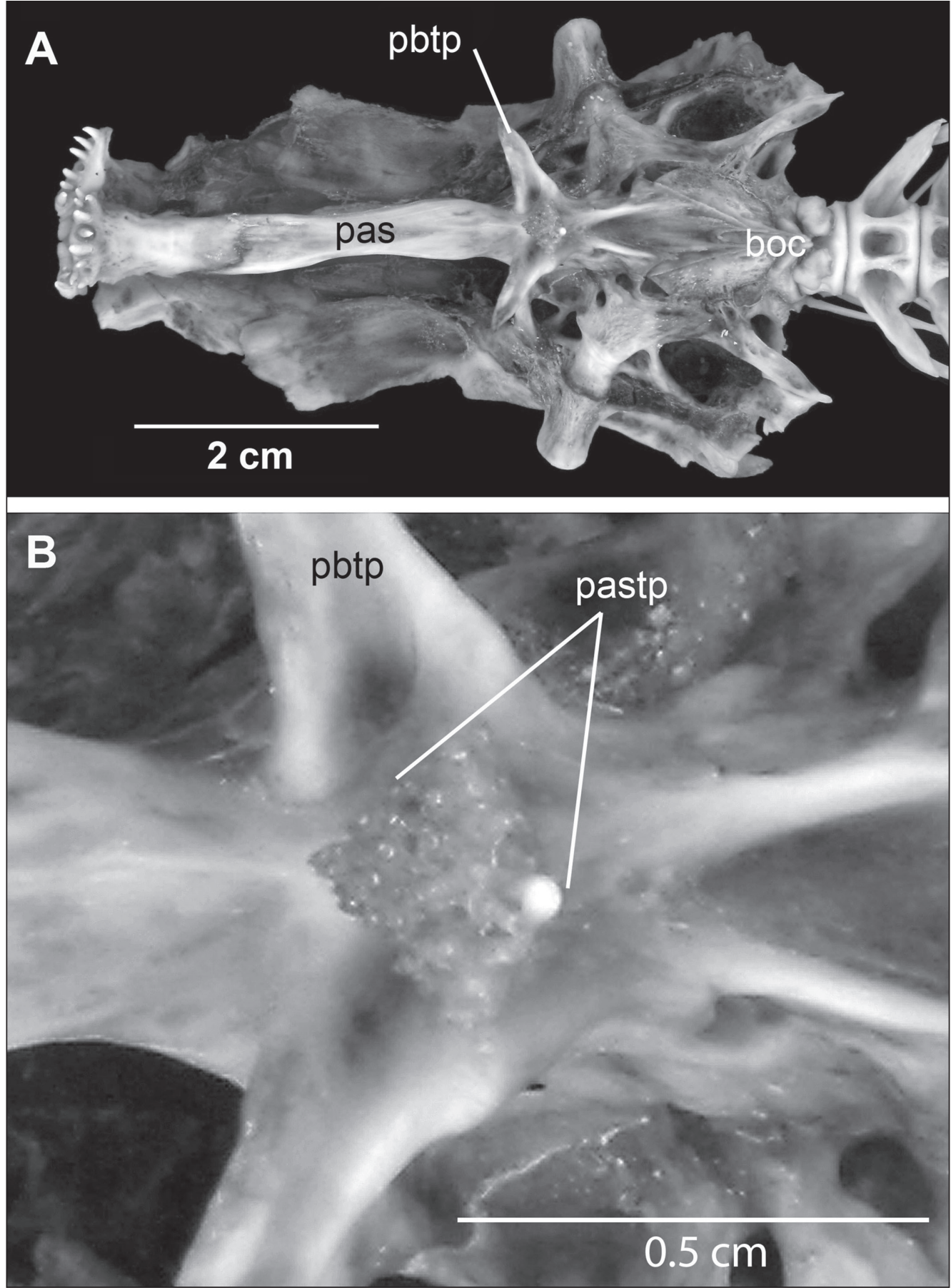

Figure 4. Osteoglossum bicirrhosum (VIMS 35991). (A) Ventral view of braincase. (B) Close-up of central portion of the parasphenoid showing the similar morphology to that of the fossil recovered from the Nanjemoy Formation. Anterior to left. Abbreviations: boc $=$ basioccipital, pas $=$ parasphenoid, pastp $=$ parasphenoid tooth patch, pbtp $=$ basipterygoid process of the parasphenoid. 
parasphenoid described herein resembles that of osteoglossines (see above), so we identify it as belonging to a member of the family Osteoglossidae.

The osteoglossid genus $†$ Brychaetus is known from fragmentary specimens from several Eocene localities throughout Europe, Africa, Asia, and North America (Hilton and Lavoué 2018). The type species for the genus, $\uparrow B$. muelleri, is known from relatively intact specimens of skulls as well as other more fragmentary specimens from the London Clay (e.g., Casier 1966). The distinctive teeth of this species (Fig. 5A) have allowed more fragmentary material (e.g., isolated teeth or broken jaws) from other localities, including the Nanjemoy Formation (Fig. 5B), to be referred to $\dagger$ Brychaetus or at least $\dagger$ Brychaetus-like forms (e.g., USNM 265383, illustrated in Weems and Horman 1983). Related taxa (e.g., some †Phareodontinae) have similar tooth morphology, although the collar is much less well developed (Forey and Hilton 2010).
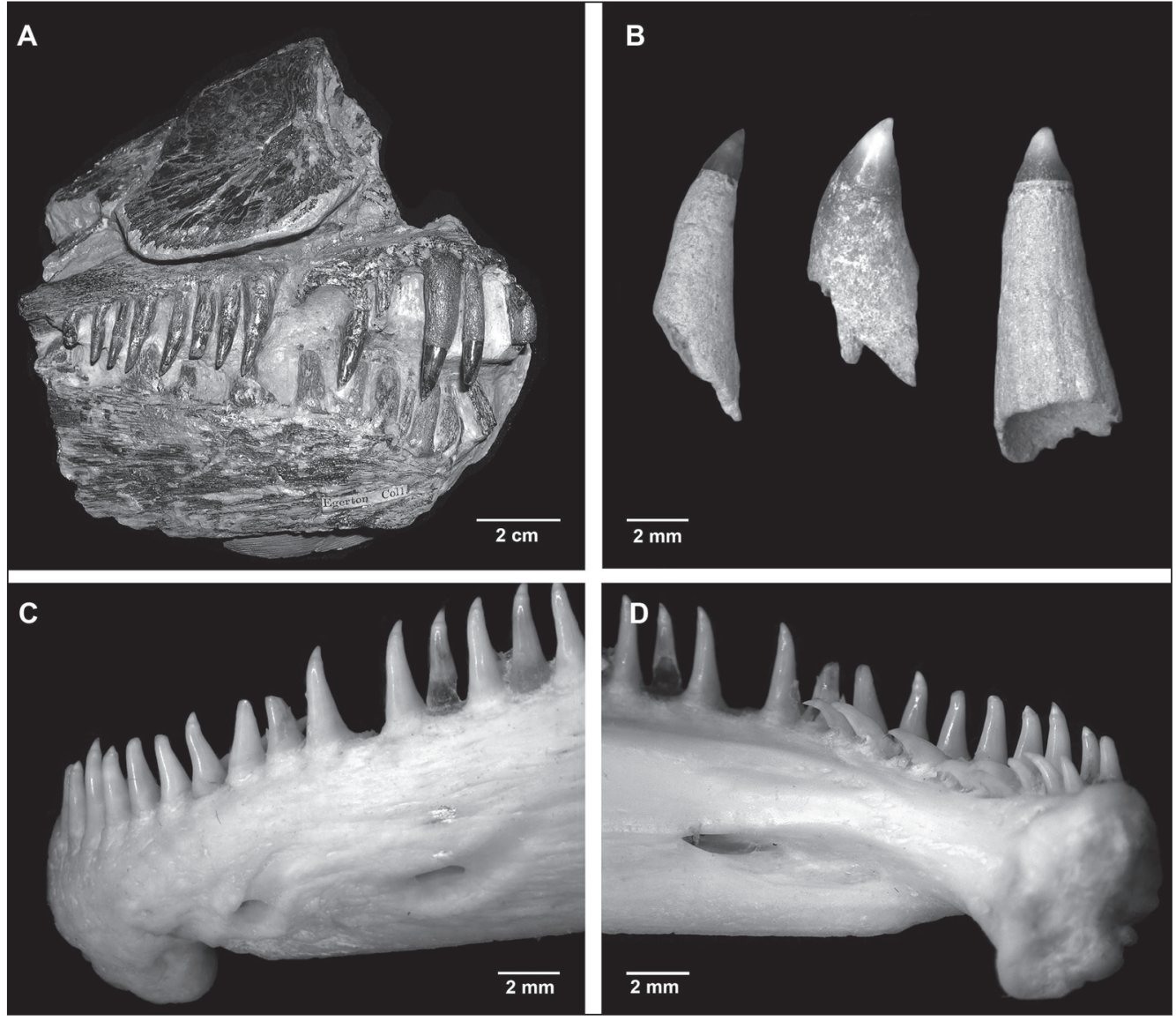

Figure 5. (A) †Brychaetus muelleri, Eocene London Clay (BMNH 1748, anterior to right). (B) $\dagger$ Brychaetus-like teeth from the Nanjemoy Formation, lateral view. (C) Lateral (anterior facing left) and (D) medial (anterior facing right) views of the tip of the lower jaw of Osteoglossum bicirrhosum (VIMS 35991) showing teeth with a morphology distinct from that of $\dagger$ Brychaetus-like specimens. 
Because $†$ Brychaetus-like teeth are well represented in the Nanjemoy, it is tempting to assign the fragmentary parasphenoid to $\dagger$ Brychaetus, as was done for the dentition (e.g., Weems and Horman 1983). However, all specimens of $\uparrow$ Brychaetus from the London Clay examined by the first author lack exposed parasphenoids, so direct comparison of the parasphenoid of $\uparrow B$. muelleri to the parasphenoid described herein is not possible. Unpublished computed tomography data of $\uparrow B$. muelleri suggests that the parasphenoid lacks teeth in this taxon (Capobianco and Friedman, University of Michigan, Ann Arbor, MI, 2019 pers. comm.). All known specimens of $\uparrow$ Brychaetus are relatively large; the morphology of the parasphenoid for juvenile specimens of $\uparrow$ Brychaetus of comparable sizes to that of the fossil described herein is unknown. Edentulous parasphenoids also are present in other osteoglossids, both fossil (e.g., †Phareodus; Li et al. 1997; E.J. Hilton, pers. observ.) and living (e.g., Heterotis, Hilton 2003:fig. 16G), but the morphology of the parasphenoids in these taxa is quite different from that of the fossil described herein. The parasphenoid described herein, although fragmentary, is similar to that of extant osteoglossines (Fig. 4), and very much unlike that of other $\uparrow$ phareodontines for which the parasphenoid is known (e.g., †Phareodus). Also, the teeth of extant osteoglossines (e.g., Fig. 5C, D) are not $\uparrow$ Brychaetus like in their morphology (e.g., they have no bony collar). Therefore, this fossil provides evidence for 2 distinct osteoglossomorphs from the Nanjemoy Formation. Until more complete material is recovered, the precise identity of both the $\dagger$ Brychaetus-like teeth and the parasphenoid represented by the taxon described herein will remain unclear.

Although most of the actinopterygian fishes known from the Nanjemoy Formation represent marine taxa, as would be expected in a glauconite-rich deposit in the Atlantic Coastal Plain, several relatively rare taxa known from this locality either are freshwater (e.g., Amiidae), primarily freshwater taxa known to inhabit estuarine and occasionally fully marine environments (e.g., Lepisosteidae), or anadromous taxa (e.g., Acipenseridae) (Weems 1999). †Brychaetus and numerous other fossil Osteoglossidae have been recovered from unquestionably marine environments (Forey and Hilton 2010), indicating that some members of this family are marine fishes. However, because the Fisher-Sullivan fauna is demonstrably a mixed marine, estuarine, and freshwater assemblage, it cannot be assumed that the parasphenoid described herein was from a marine fish. Its similarity to freshwater osteoglossines as well as its rarity at this site suggest that it represents a fish that normally did not inhabit coastal marine waters.

\section{Acknowledgments}

We thank the late Mr. Russel Sullivan for access to the site and for allowing collection of this and other specimens. This is contribution number 3854 of the Virginia Institute of Marine Science, William and Mary. 


\section{Literature Cited}

Bonde, N. 2008. Osteoglossomorphs of the marine Lower Eocene of Denmark, with remarks on other Eocene taxa and their importance for palaeobiogeography. Pp. 253-310, In L. Cavin, A. Longbottom, and M. Richter (Eds.). Fishes and the Break-up of Pangea. Geological Society Special Publication 295, London, UK. 392 pp.

Casier, E. 1966. Faune ichthyologique du London Clay, text and atlas. British Museum (Natural History) London, UK. 496 pp.

Forey, P.L., and E.J. Hilton. 2010. Two new Tertiary osteoglossid fishes (Teleostei: Osteoglossomorpha) with notes on the history of the family. Pp. 215-246, In D.K. Elliott, J. G. Maisey, X. Yu, and D. Miao (Eds.). Morphology, Phylogeny, and Paleobiogeography of Fossil Fishes. Verlag Dr. Friedrich Pfeil, Munich, Germany. 472 pp.

Hilton, E.J. 2003. Comparative osteology and phylogenetic systematics of fossil and living bony-tongue fishes (Actinopterygii, Teleostei, Osteoglossomorpha). Zoological Journal of the Linnean Society 137:1-100.

Hilton, E.J., and S. Lavoué. 2018. Review of the systematic biology of fossil and living bony-tongue fishes, Osteoglossomorpha. Neotropical Ichthyology 16(3):e180031. DOI: 10.1590/1982-0224-20180031.

Li, G.-Q., L. Grande, and M.V.H. Wilson. 1997. The species of Phareodus (Teleostei: Osteoglossidae) from the Eocene of North America and their phylogenetic relationships. Journal of Vertebrate Paleontology 17:487-505.

Murray, A.M., Y. Zaim, Y. Rizal, Y. Aswan, G.F Gunnell, and R.L. Ciochon. 2015. A fossil gourami (Teleostei, Anabantoidei) from probable Eocene deposits of the Ombilin Basin, Sumatra, Indonesia. Journal of Vertebrate Paleontology 35(2):e906444. DOI: 10.1080/02724634.2014.906444.

Sabaj, M.H. 2019. Standard symbolic codes for institutional resource collections in herpetology and ichthyology: An online reference. Version 7.1 Available online at https://asih. org/standard-symbolic-codes/about-symbolic-codes. Accessed 20 August 2019.

Weems, R.E. 1999. Actinopterygian fishes from the Fisher/Sullivan site. Pp. 53-100, In R.E. Weems and G.J. Grimsley (Eds.). Early Eocene Vertebrates and Plants from the Fisher/Sullivan Site (Nanjemoy Formation) Stafford County, Virginia. Virginia Division of Mineral Resources Publication 152, Charlottesville, VA. 159 pp.

Weems R.E., and G.J. Grimsley 1999. Introduction, geology, and paleogeographic setting. Pp. 1-10, In R.E. Weems and G.J. Grimsley (Eds.). Early Eocene Vertebrates and Plants from the Fisher/Sullivan Site (Nanjemoy Formation) Stafford County, Virginia. Virginia Division of Mineral Resources Publication 152, Charlottesville, VA. 159 pp.

Weems, R.E., and S.R. Horman. 1983. Teleost fish remains (Osteoglossidae, Blochiidae, Scombridae, Triodontidae, Diodontidae) from the Lower Eocene Nanjemoy Formation of Maryland. Proceedings of the Biological Society of Washington 96:38-49. 
Reproduced with permission of copyright owner. Further reproduction prohibited without permission. 